NBER WORKING PAPER SERIES

FROM OBSCURITY TO NOTORIETY:

A BIOGRAPHY OF THE EXCHANGE

STABILIZATION FUND

Anna J. Schwartz

NBER Working Paper 5699

NATIONAL BUREAU OF ECONOMIC RESEARCH 1050 Massachusetts Avenue

Cambridge, MA 02138

August 1996

This paper is part of NBER's research program in Monetary Economics. Any opinions expressed are those of the author and not those of the National Bureau of Economic Research.

(C) 1996 by Anna J. Schwartz. All rights reserved. Short sections of text, not to exceed two paragraphs, may be quoted without explicit permission provided that full credit, including $\odot$ notice, is given to the source. 


\title{
FROM OBSCURITY TO NOTORIETY: A BIOGRAPHY OF THE EXCHANGE STABILIZATION FUND
}

\begin{abstract}
The U.S. Treasury's $\$ 20$ billion loan to Mexico in January 1995 from the Exchange Stabilization Fund (ESF) brought to public notice the fund that had functioned in obscurity since its authorization by the Gold Reserve Act of January 31, 1934. The design of the ESF, as set forth in the statute, contributed to its obscurity. Its stated mission was to stabilize the exchange value of the dollar, but it has also assumed a role that had no mandate, that of lender to favored countries. ESF's intervention activities and the Federal Reserve's warehousing of ESF foreign currency assets are questionable. A statistical profile of the ESF accounts for the growth of its working balance from \$200 million in 1934 to $\$ 42.6$ billion in assets in 1995 .
\end{abstract}

Anna J. Schwartz

National Bureau of Economic Research

50 East 42nd Street, 17th Floor

New York, NY 10017-5405

aschwar1@email.gc.cuny.edu 
From Obscurity to Notoriety: A Biography of the Exchange Stabilization Fund

ANNA J. SCHWARTZ

The Exchange Stabilization Fund (ESF), an institution that has been in operation since shortly after it was established by the Gold Reserve Act of January 31, 1934, was remarkably little known before January 1995, when the U.S. Treasury loaned Mexico $\$ 20$ billion from the ESF as part of a rescue package. What made the loan notorious was that it did not require Congressional authorization but could be made at the discretion of the Secretary of the Treasury, with the approval of the President. In February 1996, the Treasury Department announced that it was suspending payment of interest on government securities in the ESF's portfolio in order to create additional borrowing power for the government under the debt ceiling that Congress was refusing to raise. These actions brought the fund to public notice after it had remained so long in obscurity.

The fund began operations as of April 27, 1934, financed by $\$ 2$ billion of the $\$ 2.8$ billion paper profit that the government realized from devaluation, that is, from raising the price of gold to $\$ 35$ an ounce from $\$ 20.67$. This sum was deposited to its account with the Treasurer of the United States (Treasury AR 1935, Exhibit 40, p. 265). The fund was authorized to deal in gold and foreign exchange in order to stabilize the exchange value of the dollar, to invest any portion of the fund not currently required for stabilization purposes in direct obligations of the United States, and to add any earnings from sales and interest on its investments to the sum available 
for its use. 1

of the $\$ 2$ billion set aside for ESF capital, only $\$ 200$ million was made available for its working fund. The $\$ 1.8$ billion was shown in the gold asset and liability statement of the Treasurer of the United States as gold credited to the ESF. The residual $\$ 200$ million was presumably initially deposited in a special account at the New York Federal Reserve Bank, but by June 1934 the ESF had reduced the deposit by investing $\$ 38$ million in U.S. Treasury bonds, $\$ 20$ million in gold (the bulk held at the U.S. Assay office), and $\$ 30$ million in silver.

The ESF was established at a time when the dollar was pegged to the price of gold but not to the exchange value of other currencies. It was expected to function in just such an international monetary system. The expectation, however, proved false, and the ESF had to adapt to the changing international monetary system over the six decades that followed.

The rest of the paper is organized as follows. In section 1 I examine the design of the ESF as set forth in the statute, in particular, the provisions that contributed to its obscurity. In section 2 I describe the mission of the ESF as defined in the statute and as the mission developed in the unexpected circumstances in which it operated. I conclude the section with a statistical profile of the ESF that reflects the missions it serves. In section 3 I assess the influence of the ESF in a broader context than its role in the 1995 Mexican bailout.

1. DESIGN OF THE ESF

The act creating the ESF excluded it from the congressional appropriation process once its initial capitalization was in place. It was intended to be self-financing, and was not required to seek annual 
congressional funding for its operations. ${ }^{2}$ The self-financing arrangement contributed to the secrecy of ESF actions, since the fund did not have to justify its expenditures during annual appeals to Congress for appropriations. The ESF has increased the $\$ 200$ million working balance it started with in 1934 to $\$ 42$ billion in June $1995 .^{3}$ The statistical profile that I present at a later point shows how the ESF achieved this increase.

The fund was conceived to operate in secrecy under the exclusive control of the Secretary of the Treasury, with the approval of the President, "whose decisions shall be final and not subject to review by any other officer of the United States" (PL 87-73, sec. 10(b)). The intention was to cloak foreign exchange market intervention. However, the Secretary of the Treasury was willing to reveal information on stabilization loans to favored countries that the ESF negotiated -- loans that had no mandate in the statute yet essentially created a foreign affairs role for the Treasury.

The secrecy promoted two abjectives. One was to conceal from the public and Congress the exchange rates at which foreign currencies were bought and sold, particularly if they involved losses. A second objective was to permit the Treasury, if it so desired, to conceal information about any other operations the ESF might undertake. "The ESF in any event could base the secrecy of its operations on the British Exchange Equalisation Account (EEA), formally initiated July 1, 1932. It was described as "an anonymous and secret body whose actions are not open to continuous scrutiny and criticism" (Hall 1935, p. 81). The House of Commons did not know and could not be told what the EEA was doing (Drummond 1981, p. 188). One feature of the model was not, however, copied. To operate the EEA, Parliament appropriated 175 million pounds in Treasury bills, an amount that in later years was sizably increased 
(Sayers 1976, II, P. 427, PP. 487-88). ${ }^{5}$

Suspicion of the purpose of the EEA was a motive for the establishment of the ESF. U.S. officials believed that the EEA was used to depreciate the pound, not to smooth fluctuations in its exchange rates, its official purpose (Drummond 1981, p. 195). Each fund would have liked to know what the other's intentions and actions were.

The secrecy in which both the ESF and the EEA were designed to operate was subsequently modified. A 1977 amendment to the Gold Reserve Act (31U.S.C.§ 5302(b)) provided that an ESF loan or credit to a foreign entity or government for more than 6 months in any 12 -month period required the President to give Congress "a written statement that unique or emergency circumstances require the loan or credit for more than 6 months." A 1978 amendment (31 U.S.C.§ 5302 (c) (1) provided for a monthly statement to the House and Senate Banking Comnittees by the Treasury "on all agreements made or renewed, all transactions occurring during the month, and all projected liabilities" of the ESF .

No change has occurred in the status of the Secretary's decisions as final, and not subject to review. In testimony before the House Banking Committee in 1990, however, a Treasury official indicated that the department would be amenable to review by Congress of this "veil of the greatest secrecy" (Mulford, Hearings 1990 , p. 62).

The ESF's administrative expenses have been subject to the budget process since 1979. In addition, the ESF is audited annually, with the report originally submitted to the President, not to Congress. Later, Section $\$ 5302$ (c) provided that Congress should also receive reports on the ESF's operations. 
The response of the Republican Congress to the President's authorization of the ESF grant of $\$ 20$ billion in medium-term loans to Mexico in January 1995 less any outstanding short-term loans and securities guarantees was to pass the Mexican Debt Disclosure Act of April 5, 1995. It directed the administration to provide a broad range of documents, some of them classified, about the bailout, before Mexico could obtain more money from the ESF.

Although Congress has required the President to give it information about ESF transactions, the constitutionality of the ESF has not been challenged. The ESF in its original design as a creature of the Executive Branch, immune to legislative oversight, breaches the separation of powers. It is hard to believe that a fund with similar powers would win legislative approval currently. In 1934, of course, New Deal legislation by and large was initiated by the administration, Congress rubber-stamping what was put before it. Ordinary citizens have no standing to mount a challenge to the constitutionality of the ESF, and sixty years after its creation, it is unlikely to happen.

2. MISSION OF THE ESF

A. Foreign Exchange Market Intervention

The statute authorized the ESF to deal in gold $d^{6}$ and foreign exchange. To a limited extent it was involved in such transactions during the 1930s, but it was not until 1961 that it became active in the foreign exchange market. The reason was that, except during its initial years, the international monetary system in which the ESF existed did not conform to the expectations of the degigners of the agency.

The record of ESF foreign exchange market intervention thus falls into two periods: the period before 1962, when little opportunity for intervention 
arose, and the period that followed, when the ESF enligted the Federal Reserve to join it in intervening in the foreign exchange market. I begin by summarizing the few highlights of the first period.

Pre-1962 Intervention. The ESF dealt in foreign exchange only prior to world War II. A gtatement by Treasury Secretary Morgenthau on February 11, 1935, apparently alluded to the ESF's first and only foreign exchange purchase until 1936 -- sterling amounting to $\$ 21,000$ : "When we saw that the external value of the dollar was rapidly going out of control, we put the stabilization fund to work on a moment's notice, with the result that for the past four weeks we have successfully managed the value of the dollar in terms of foreign currencies. The country can go about its business with assurance that we are prepared to manage the external value of the dollar as long as it may be necessary" (Treasury AR 1935, Exhibit 40, p. 235).

The decline in buying rates for the pound from November 1934 through March 1935 apparently led Morgenthau to believe that the British were deliberately depreciating the pound. Why he concluded that he had "successfully managed the value of the dollar" is not obvioug since the pound did not strengthen for six weeks following his self-congratulatory statement. Another example of Morgenthau's readiness to believe that exchange rate movements were designed to be destabilizing when in fact they were routine occurred in September 1936. The Russians then offered to sell 1 million pounds which the ESF bought on the Treasury's off-hand assumption that the sale was intended to drive down the pound, a result that its purchase thwarted. That very day the Treasury changed its mind about the Russian motive (Paris 1938, p. 31).

The secrecy of ESF operations was breached in June 1935, when the franc 
was under attack and the president of the French central bank publicly thanked Morgenthau for the ESF purchase of francs, much to Morgenthau's embarrassment (Paris 1938, P. 31).

Tripartite Agreement of 1936. In September 1936 the U.S., U.K., and French governments gimultaneously issued declarations accepting a devaluation of the French franc and agreeing to use appropriate available resources to avoid digturbance of international exchanges resulting from the readjustment. The appropriate available resources were those of their exchange equalization funds, the French having used more than half of the devaluation capital gain to establish a newly created stabilization fund. The three governments agreed to guarantee exchange rates for 24 hours at a time, authorities of the stabilization funds announcing each morning the price at which they would convert into gold at the end of the day on a reciprocal basis the foreign currency balances the others had acquired. The U.S., which had previously sold gold at $\$ 35$ an ounce, plus handling charges, only to gold-standard countries, announced it would sell gold to stabilization funds. The arrangement eliminated exchange risk for the authorities while preserving exchange-rate flexibility. Belgium, the Netherlands, and Switzerland were soon added to the nations complying with the Tripartite Agreement and eligible to buy gold from the United States.

By World War II the ESF had sold off modest amounts of sterling, francs, and belgas it had acquired by participating in the Tripartite Agreement. During the war the ESF held Swigs francs and balanceg in foreign currencies at depositories abroad. It made the Swiss francs "available for governmental and humanitarian purposes," according to the Treasury's statement (Treasury AR 1945, P. 95). 
Post-Bretton Woods Change in ESF. As early as 1943 the Treasury Department tentatively proposed the establishment of an international stabilization fund postwar to which all United Nations members would belong -- the original model of the IMF, of which Harry Dexter White was the designer (Treasury AR 1943, p. $116 ; 1944$, pp. $96-7 ; 1945$, pp. $95-6) .^{7}$

The U.S. Bretton Woods Agreement Act (PL 171-79) of July 31, 1945, made a change with long-term effects on ESF operations. That change was the provision in Sec. 7 that amended the Gold Reserve Act. ${ }^{8}$ The amendment directed the Secretary of the Treasury to use $\$ 1.8$ billion of the ESF capital (shown on the balance sheet as cash in the form of gold held by the Treasurer of the United states) to pay part of the $\$ 2,750$ million U.S. subscription to the IMF. By June 1946, the United States had paid $\$ 275,000$ of its subscription (Treasury AR 1946, p. 83). It completed payment of its subscription on February 26,1947 , in the form of $\$ 687.5$ million in gold, $\$ 280.5$ million in cash, the remaining $\$ 1,782$ million in nonnegotiable noninterest-bearing notes, payable on demand in dollars when needed by the IMF (Treasury AR 1947, p. 48). From 1946 until 1961 the ESF held no foreign exchange of the industrialized countries. A role for an exchange stabilization fund would seem to have been obviated once the IMF was in place to manage exchange rateg, but the ESF regarded the IMF as needing its support. Balance-of-Payments Concerns. A deterioration in the U.S. balance of payments, as measured by outflows of gold and dollars to countries in surplus, aroused the concern of the Kennedy administration when it took office in January 1961. The loss of gold to foreigners in that month was seen as an expression of a lack of confidence in the administration's commitment to a dollar convertible into gold at a fixed price. The twin goals became to eliminate the balance-of- 
payments deficit and to check speculation against the dollar. To achieve the second goal the Treagury wanted to be in the same position as other countries that influenced the exchange value of their currencies. That required resources to buy and sell other currencies or, in official parlance, sales and purchages of dollars.

To that end the ESF began to operate directly in the foreign exchange market. By June 1961 it had bought spot $\$ 25.4$ million sterling, $\$ 20.1$ million D-marks, and $\$ 65$ million Swigg francs to counter threatg against the dollar.

In March 1961, after revaluations of the D-mark and the Dutch guilder, the ESF made forward sales of D-marks to drive down the forward premium on the mark (discount on the dollar). The Treasury's forward mark commitments were liquidated by early December; it used marks it had acquired in April 1961 from a German debt repayment to the United States to settle in part forward contracts that were maturing in the fall of 1961.

There were similar forward operations by the Treasury in Swiss francs and Dutch guilders to bring down the premium on these currencies. As a response to the rise in the exchange value of the Italian lira in 1961 to its upper limit against the dollar, the Treasury took over forward lire contracts from the Italian foreign exchange office and drew on a $\$ 150$ million line of credit in lire it obtained by issuing three-month certificates of indebtedness to support spot and forward operations in lire. As a result dollar accumulationg in Italy were lessened.

Even these limited operations strained the resources of the ESF. In June 1961 it had $\$ 200$ million capital plus $\$ 136$ million in net earnings accumulated over itg 27-year life. Average annual net earnings approximated $\$ 5$ million, from income on gold bullion sales, gold and exchange transactions, and 
interest on its government securities portfolio. To finance its foreign exchange purchases of roughly $\$ 100$ million in 1961 , the ESF had reduced its account at the Federal Reserve Bank of New York by $\$ 91$ million and sold U.S. government securities.

The Treasury's immediate aim was to find ways to supplement ESF foreign currency balances.' It did so first by persuading the G-10 countries to create a facility that would expand the IMF's ability to lend. The IMF held only about $\$ 1.5$ billion in currencies other than dollars. The new facility, establighed in December 1961, was the General Arrangements to Borrow (GAB), which provided the IMF with a $\$ 6$ billion line of credit from central banks in surplus to assist countries in deficit, in particular, the United stateg. The U.S. quota in the IMF was nearly $\$ 6$ billion, so it could not draw enough to meet its reserve needs; the GAB was intended to serve as a supplementary source of liquidity for the United States. The IMF would sell to the United Stateg for dollars foreign convertible currencies borrowed from other countries. These currencies would enable the United States to buy up dollars offered in the market and to redeem dollars foreign central banks did not want to hold, thus maintaining U.S. monetary gold reserves.

The Treasury next persuaded the Federal Reserve to serve as its partner in exchange market intervention. So begins the second period of ESF intervention operations.

The Federal Reserve as ESF Partner. The Federal open Market Committee (FOMC) authorized open market transactions in foreign currencies for the account of the Federal Reserve System on February 13, 1962. Before that date the Federal Regerve Bank of New York served as the agent only of the ESF in executing itg limited foreign currency transactions. Since that date it has served both the 
ESF and the Federal Reserve System. In support of its decision to engage in intervention operations, the FOMC cited "the need to supplement the relatively small resources which the Treasury stabilization Fund had available and had been using to defend the dollar from speculative attack in the foreign exchange markets since 1961" (Board AR 1962, p. 11). Since this paper is a study of the ESF, I shall refer to the Federal Reserve's operations only in relation to the conduct of the ESF. The firgt imperative for the Federal Reserve, once it determined that it had the legal authority to intervene, was to acquire foreign currencies for its future operations. It did so by purchasing from the ESF in 1962 dollar equivalents of $\$ 32$ million in D-marks, and of one-half million dollars each in swiss francs, Dutch guilders, and Italian lire to open accounts at the central banks that issued these currencies.

This initial Federal Reserve purchase of currencies owned by the ESF has been cited as the origin of "warehousing," the euphemism that later came into use to describe the provision of funds to the ESF outgide the Congressional appropriations process (Todd 1992, pp. 132-33). ${ }^{10}$ It was not until 1977, however, that warehousing of foreign currencies for the ESF was formally authorized by the Federal Reserve. I shall discuss warehousing in a moment as one of the ways that ESF funds its currency acquisitions.

During the Bretton Woods period, except for forward purchases and sales of foreign currencies, the ESF rarely participated in interventions, which were for the most part financed by drawings on Federal Reserve swap lines." It was only beginning in 1978, after the formal authorization of warehousing that the ESF jointly intervened with the Federal Reserve. The prearranged share of the ESF varied from a little more than 10 of of the foreign currency 
purchase or sale to half (more than half in the case of marks, since the ESF had a swap line with the Bundesbank), and the Federal Reserve took the remaining share. Shares tended to be equal during the limited interventions of 1981-85. Since 1987, shares have varied from equal percentages to threequarters for the ESF, one-quarter for the Federal Reserve. In addition to its swap line with the Bundesbank, the ESF also had a line with the central bank of the Netherlands, 1962-69.

The ESF as Principal. There are nuances in the relation of the ESF as principal to its agent, the Federal Reserve. Paul Volcker emphasizes that the Treasury does not have authority to instruct the Federal Reserve to spend its own money on intervention and to take the attendant risks, and that the Treasury would be reluctant to intervene over strong objections of the Federal Reserve (Volcker and Gyohten, 1992, p. 234). The FOMC, at its March 27, 1990, meeting, argued in favor of continuing to intervene, despite misgivings about the effectiveness of intervention, as a means of moderating Treasury initiativeg (Transcript, 1990).

At the start in 1962 of Federal Reserve participation for its own account, it was an eager agent, ready to support the principal and enthusiastic about defending the dollar under the Bretton Woods system. Even as disillusion with the results emerged when foreign currency balances ballooned in the late 1980s, there was no consensus in the FOMC to end its supporting role. It clearly did not want to challenge the Treasury's role as its superior.

Sources of ESF Funds. Since the ESF sought to expand its operations after 1961, despite limited resources, it developed a range of means to do so. The Treasury in addition to the establishment of the GAB relied for the most part 
on other forms of borrowing that of courge had to be repaid.

One means was a U.S. drawing on itg IMF quota, by which it purchased foreign currencies for dollars, payable over a 3- to 5-year period. These drawings that were turned over to the ESF occurred during $1964-66$ (\$1.6 billion), 1968 ( $\$ 0.2$ billion), 1970-72 ( $\$ 1.7$ billion), and 1978 (\$3 billion). Warehousing by the Federal Reserve of ESF foreign currencies was formally authorized on January 17,1977 , for up to $\$ 1.5$ billion, increased in 1978 firgt to $\$ 1.75$ and then to $\$ 5$ billion, limited to 12 months, with no limit on the term in 1980 . The ceiling was raised to $\$ 10$ billion in 1989 , and to $\$ 15$ billion in 1990 . The amounts held in the warehouse tended to rise with the authorized amounts. In 1991 the ceiling was lowered to $\$ 10$ billion and in February 1992 to $\$ 5$ billion. The ESF repurchased amounts in the warehouse in 1990-92 when it was emptied. The ceiling was raised to $\$ 20$ billion in January 1995 at the time of the Mexican bailout. No use has, however, been made of the warehouse since 1992.

Another source of ESF funds was the sale of Treasury securities denominated in foreign currencies. These issued in 1962-74 were known as Roosa bonds and in 1978-79 as Carter bonds, in the former years to official institutions in half a dozen countrieg (Austria, Belgium, Germany, Italy, Netherlands, and Switzerland) and the Bank of International settlements, in the later years to German and Swiss private investors. Net amounts issued in different foreign currencies in the former period totaled $\$ 4.67$ billion, $\$ 6.44$ billion in the later period. By 1983 all issues had been redeemed, with losses on Swiss francs in 1972-73, 1978-79, and 1981. The ESF's net losses in 1972-73 were \$165 million; in 1978-79, \$1 billion; and in 1981, \$573 million. The one new source of funding that created a net addition to the ESF's 
resources was the issue of Special Drawing Rights (SDRs) by the IMF.

Allocations to the Treagury in $1970-72$ amounted to $\$ 2.29$ billion, in 1977 to $\$ 0.87$ billion, and in $1980-81$ to $\$ 1.73$ billion. The Federal Reserve monetized SDRs for ESF use, crediting dollar amounts of the SDRs to ESF deposit balances at the Federal Reserve, and these dollar amounts appear ag SDR agsets on ESF balance sheets. Table 1 below showg the importance of the SDR contribution to the growth of ESF resources.

Record of Intervention. During the Bretton Woods era intervention was directed to protect the value of dollars held by foreign central banks in order to deter their exchange for U.S. gold. Rather than sell gold, the United States borrowed foreign currencies to buy dollars held abroad. To repay the borrowed foreign currencies, the proceeds of the sale of Treasury bonds denominated in foreign currencies were used. As the decade of the 1960s progressed, the authorities intervened massively in every major currency. The defense of the dollar during the Bretton woods period, however, failed, since the policies to correct the U.S. balance of payments and dollar overvaluation were inadequate. When the United States closed the gold window on August 15, 1971, it turned from defense of the dollar valued in gold at $\$ 35$ an ounce to dollar devaluation.

With the demise of Bretton woods and the coming of floating exchange rates, the ESF and the Federal Reserve have nevertheless persisted in efforts to manage exchange rates, despite the interval from 1981 to early 1985 when intervention lost political favor. The record since then suggestg that large and reversible transitory movements of some exchange rates and widening of bid-agk spreads may be temporarily reduced by intervention. There is no indication, however, that, the frequent action of the U.S. authorities to 
quell disorderly markets, has had any permanent effect.

Whether the dollar is deemed strong or weak, intervention does not deal with the fundamental economic conditions that underlie medium-term changes in the exchange value of the dollar. The feared changes of medium-term variations in the dollar's exchange value have not materialized. The supposedly grossly overvalued dollar in 1981-85 did not deindustrialize the U.S. economy and usher in a service economy of low-income occupations. Similarly, concern that a weak dollar would induce domestic inflation has not been substantiated. In general, the costs of floating exchange rates should be compared to the costs of the alternative, which is fixed or pegged exchange rates, vulnerable to speculative attacks and bigger adjustments.

Why Warehousing? Two aspects of intervention merit comment. One is the practice of warehousing by the Federal Reserve and the Treasury. It seems to contravene the statutory prohibition of the direct financing of the Treasury by the Federal Reserve (Todd 1992, pp.140-41). The transcript of the FOMC's March 27, 1990, meeting reveals members' doubts about the legality of warehousing, despite the claim that the Federal Reserve General Coungel in 1962 had issued an opinion that justified warehousing as an open market purchase of foreign exchange from the Treasury. The concern was that warehousing removed from Congress the appropriation power, eliminating the necessity for the Treasury to turn to Congress to obtain funds it did not have to acquire foreign currencies. Nevertheless, at that meeting the FOMC increased the limit on warehousing from $\$ 10$ billion to $\$ 15$ billion. ${ }^{12}$ As mentioned earlier, the ceiling in 1992 was reduced to $\$ 5$ billion when the ESF repurchased its foreign currencies in the warehouse. However, the role of warehousing remains very much in question, since the FOMC raised the upper 
limit to $\$ 20$ billion on January 31, 1995 (FRB May 1995, p. 447). The expansion of the warehouse was intended to help the ESF participate in the Mexican rescue program but, in the event, it has not availed itself of this provision. Just as the courts have not tested the constitutionality of the ESF, there has been no test of the legality of warehousing.

Why Intervention? Empirical evidence offers no support for intervention operations. No theoretical model is able to predict exchange rate movements at short horizong, let alone explain exchange rate movernents ex post. What justifieg the hubris of monetary authorities that they know the secret of the foreign exchange market?

In a recent essay the president and senior vice president of the Federal Reserve Bank of Richmond argue the case for separating the Federal Reserve completely from foreign exchange operations on the ground that they imperil the credibility of monetary policy (Broaddus and Goodfriend 1996). They do not, however, recommend that the nation should forsake foreign exchange operations. In my view, intervention has proved to be a pointless activity, so I see no purpose in a continued role for either the Federal Reserve or the ESF in this connection.

B. ESF as Lender

The ESF early on discovered a purpose for its existence other than exchange market intervention -- stabilizing not the value of the dollar in exchange for the currencies of the major industrialized countries, but lending dollars to LDCs to stabilize their currencies, initially to compensate for the damaging effectg of the U.S. 1934 Silver Purchase Act. Before 1961 the only foreign currencies in the post-World War II ESF portfolio were currencies of LDCs with which it negotiated intermittent gtabilization loan programs, a form 
of foreign aid.

What was the genesis of the idea of stabilization loans? The prototype may have been the stabilization creditg extended to central banks during 192431 to facilitate their return to the gold standard. Benjamin strong and Montagu Norman actively promoted the stabilization of the newly restored European exchange rate structure post-World War I by means of credits from the Federal Reserve and other central banks (Clarke 1967).

The selection of countries to which the ESF extended loang was obviously a political decision made by the Treasury. Harry Dexter White's memoranda, written between 1936 and 1944, found among his unpublished papers, supporting loans to various countries, attest to his influence on which ones the ESF selected during this period. The countries included China, Mexico, other Latin American countries, and Russia (Harry Dexter white Papers in the Seeley G. Mudd Manuscript Library, Princeton University, box 1, items 3a, 3b; box 6 , items $14 \mathrm{a}, 14 \mathrm{~b}, 14 \mathrm{~L}, 19 \mathrm{a}$; box 11, item 28a).

Stabilization Loans. Ten Latin American countries at one time or another during the period 1936-61 had exchange stabilization agreements, often with renewals. The countries in this group were Argentina, Bolivia, Brazil, Chile, Cuba, Ecuador, Mexico, Nicaragua, Paraguay, and Peru. Mexico had the longest record of agreements, the initial ones motivated by the digturbing effects of the U.S. Silver Purchase Act of June 19, 1934, which led to a trebling of the market price of silver between 1933 and 1935 .

During World war II the mission of the ESF was expanded to include provision of dollarg to countries deemed worthy of such assistance for their importance in the war effort. In Europe only Iceland had an exchange stabilization agreement, but the ESF provided the USSR with dollars during 
World War II in exchange for gold. In Asia there were agreements with China with respect to silver, gold, and yuan from 1936 to 1943 . The EsF had wartime agreements with India, Iran, and Egypt to sell gold in exchange for local currencieg for use by U.S. personnel stationed there. It provided Liberia with U.S. currency when it converted its monetary gystem from British coins. During the postwar years ESF stabilization loan programs were combined with IMF standby arrangements, Export-Import Bank (EXIM bank) foreign currency credits, and assistance from the International Cooperation Administration and the Agency for International Development that was established in 1961. These overlapping authoritieg represented different executive departmentg including Commerce and state. The ESF contribution to these credit packages was small. One advantage of combining the ESF loan with others was that the latter often provided the LDC recipient with the means to repay the ESF.

In the period since 1962 stabilization agreements for the first time provided for reciprocal swap facilities. Previously, when the Esf gave dollars to LDC countries, a provigion of the agreement required the country to repurchase in dollars any of itg currency that the ESF might have acquired. Many of the same countries that had stabilization agreements with the ESF before 1962 were again represented in the later period. There were also some newcomers in Europe, Asia, and Africa, but Latin American countries predominated. As was characteristic of the earlier Bretton Woods years, ESF agreements were ugually combined with loang from international or other U.S. agencieg.

Latin American countries with stabilization agreements during part or all of the period included Argentina, Bolivia, Brazil, Chile, Colombia, Costa Rica, Dominican Republic, Ecuador, El Salvador, Guyana, Honduras, Mexico, 
Nicaragua, Panama, Peru, and Venezuela. European countries included Hungary, Poland, Romania, and Yugoslavia. Jamaica was the sole West Indies country, the Philippine Republic the sole Asian country, Nigeria the sole African country with a gtabilization agreement.

An appendix, available on request from the author, presents the published information in official sources about the stabilization and other agreements the ESF signed with foreign countries before and after 1962. A notable omission is any reference to the interest rate that these countries were required to pay for dollar loans.

The country with the longest and most continuous record of EsF agreements, as in the period before 1962, is Mexico. A knowledgeable observer has noted: "Since 1976 [in fact, much earlier, as shown in the appendix], the international financial community, led by the U.S. authorities, hag come to the financial agsistance of Mexico on numerous occasions. The gize and novelty of these operations may have suggested to investorg that Mexico was a different, if not unique, sovereign borrower" (Truman 1996, p. 202). In the case of Mexico, since 1967, the Federal Reserve as well ag the ESF have duplicate short-term loan programs.

Examination of the list of countries that have been granted loang over the years, as detailed in the appendix leads me to doubt that they have resulted in stabilization. What evidence is there that repeated extensions of loang helpg these countries to advance their economies? The message of the loan packages seems to be that mismanaged countries have a friend at the ESF, which will arrange a rescue. Servicing and amortizing the loans seem to add to the borrowerg' problems. Loans may be a fruitless policy for countries that have yet to develop ingtitutions that observe the eternal financial verities 
of sound figcal and monetary management.

C. Conspectus on ESF Asset Holdings

As the preceding discussion has shown, the biography of the ESF falla

into two periods. That break is also reflected in its statigtical profile (Table 1). It began operationg in 1934 with $\$ 200$ million. By 1960 it held $\$ 330$ million in assets, the cumulative net income of $\$ 130$ million over the twentyfive intervening years accounting for the increase. The slow growth was indicative of the atrophy of a foreign exchange role for the ESF during its initial quarter century and the rise of stabilization lending that it nurtured to fill the void.

The principal noncash asset of the ESF in the first period was its gold account, acquired for transactions with foreign monetary authorities and with the market, as the statute authorized. The ESF continued to hold gold in a special account of the Secretary of the Treasury at the Federal Reserve Bank of New York until December 9, 1974 (Treasury AR 1975, Exhibit 54, p. 501). The Treasury on that date consolidated three different gold accounts, including ESF gold, in its general account in anticipation of the gold auctions it conducted in 1975 and 1978-79. ESF gold was sold to the Treasury at its par value. The gold category was then eliminated from ESF assets.

U.S. government gecurities and foreign exchange assets were minor components of ESF noncash assets in the first period. Foreign exchange included currencies of LDCs at par, not market, values, and minimal amounts of currencies of industrialized countries.

It was in the second period, after 1960, that the main growth in ESF assets occurred. By 1995 ESF assets amounted to $\$ 42.6$ billion. of the increase of $\$ 42.3$ billion post-1960, the main contributors to faster growth of ESF 
assets were an increase of $\$ 29$ billion in foreign exchange asgets and the addition of the new asset of special Drawing Rights (SDRs) amounting to $\$ 11.9$ billion. Though listed as SDRs on the ESF balance sheet, they are ordinary dollar amounts, available for any use the ESF chooses.

In addition to the $\$ 4.9$ billion IMF allocation to the United states, the ESF acquired $\$ 2.6$ billion SDRs from other IMF participants (IMF 1995, p. 53). The difference between the 1995 dollar value of SDRs and the dollar value of the initial acquisitions represents the net increase in SDR valuation in dollar terms from parity in 1970 to $\$ 1.49$ in 1995. Accompanying growth of cumulative net income amounting to $\$ 26.6$ billion in the second period was an increase in foreign exchange asset growth, which was a policy objective, presumably reflecting the influence of Treasury officials who negotiated the Plaza Agreement of September 1985 and the Louvre Agreement of February 1987. The increases in foreign exchange assets was concentrated in the period after the late 1980s. The assets encompassed major country currencies as well as those of LDCs.

Holdings of U.S. government and foreign securities rose relative to their representation in the portfolio in the earlier period, but at most accounted for a third of total assets during the second period. Because ESF investments in foreign securities were either combined with U.S. government securities or foreign exchange or, if geparately shown, assigned the label of other securities, it is not possible to present them as a separate category. D. Rate of Return on ESF Assets

Table 2 shows capital gaing (logses) on gold before 1975 and amounts on foreign exchange, minor before 1975, more substantial since. If the table were annual, losses on foreign exchange, totaling $\$ 1.7$ billion, would be shown for 
1972-73, 1978-79, and 1981. These losses were incurred, ag mentioned above, when the liability for U.S. Treasury securities denominated in foreign currencies was extinguished. Interest earnings on foreign exchange, and on U.S. government and foreign securities are separate categorieg.

Finally, the table shows SDR valuation changes and interest earnings on SDRs. The IMF currently usea a basket of five currencieg for determining SDR valuation. The same basket is also used to determine the interest rate on SDRs. Before 1981 the basket included 16 currencies. The valuation is a weighted average of the exchange rates of the five currencies.

The ESF posts a liability item of SDR certificates that it owes the Federal Reserve for its SDR holdings, and a liability item of SDR allocations. representing itg obligation that would arise if the IMF were to cancel SDRs. To date no cancellation has occurred. The sum of these liability items on June 30, 1995, was $\$ 15.7$ billion. Deducting that amount from reported assets of $\$ 42.6$ billion establishes ESF net worth as no more than $\$ 26.9$ billion on that date.

Table 3 shows the rate of return of net income on total ESF assets, 1935-95, and of total return on individual assets, summing capital gains (losseg) and interest earnings of the asset categories. The data for the separate asset categories are available only beginning 1940 .

The rate of return on total ESF assets at the five-year intervals the table presents, with three exceptions, varied between lesg than 1 and 4 percent. Exceptional years are 1945 when there was a windfall on gold holdings, and 1990 and 1995, when foreign exchange, securities investments, and SDRs all yielded 5-9 percent returns. I have not seen an explanation in official gources of the gold windfall in 1945 . 
Although there were losseg on foreign exchange and SDR revaluation in the firgt quarter of 1990 , for the year ending June 30,1990 , the results were highly favorable. Similarly, foreign exchange losses and losses on SDR revaluation were recorded in the last quarter of 1994, but for the year ending June 30,1995 , the results were even more favorable than in 1990 . In the quarter ending September 30, 1995, the last one for which information has been released, the ESF sugtained a $\$ 2$ billion realized loss on its foreign exchange portfolio and a $\$ 168$ million loss for change in valuation of its SDR holdings. Foreign exchange assets in 1990 included besides marks and yen, small amounts of sterling and Swiss francs, and an assortment of LDC currencies (Mexican pesos, Hungarian forints, Guyana dollars, Honduran lempuras). By 1995 the portfolio was restricted to marks and yen and Mexican pesos. With a weak dollar, the value of foreign currencies appreciated, and increases in SDR assets accompanied increases in revaluations of the SDR against the dollar between 1990 and 1995.

The ESF does not purgue positive rate of return results. Negative results apparently are compatible with the missions it fulfills. It has not, however, consistently logt money.

\section{AN ASSESSMENT OF THE INFLUENCE OF THE ESF}

The ESF was originally established for a two-year period and subsequently given repeated two-year extensiong until it was made permanent. It was not exposed to scrutiny by either Congress or by Democratic and Republican Administrations until the events of January 1995.

The belated attention paid to the ESF because of its role in the Mexican bailout misses a broader measure of its influence. The true significance of the ESF lies not in its domestic aspect -- a small agency in the U.S. Treasury 
Department, engaged in masterminding foreign exchange market intervention and acting as a benevolent lender to small troubled countries. What is more noteworthy is the influence of ESF practice on the way the postwar international monetary system, with the IMF at its center, has operated.

The ESF appears to be the prototype of the IMF. "The germ of the idea of combining regulatory and financial provisions that is so prominent a feature of the IMF" has been linked to the bilateral ESF agreement of November 1941 with Mexico. Like the ESF agreement, "the basic transactions of the IMF to assist its member countries also involve exchanges of currency" (Gold 1988, p. 1127). The IMF is said to have adopted the ESF form of exchanges of the currencies of the two contracting parties and not loans by one party to the other, to avoid the "indignity that might seem to attach to borrowing." This may be IMF decorum, but no one believes that the exchange of pesos for dollars ig a trangaction other than a loan of dollarg.

The legacy of the ESF is that lending programs dominate the operation of the IMF. Support for weak currencies that the IMF provides raises problems of moral hazard. Whether IMF lending has good or bad consequences is a question beyond the scope of this paper. ${ }^{13}$ 


\section{Endnotes}

1. Harry Dexter White (Treasury Director of Monetary Research, 1938-45; Assistant Secretary of the Treasury, 1945-46) was appointed on December 15, 1941, to manage the operation of the ESF and to act as liaison between the Treasury and the State Department on all matters having a bearing on foreign relations (Treasury AR 1942, Order No. 43, 335). In an unpublished, undated, memorandum on stabilization funds and international trade, he described stabilization funds as "a convenient instrument to countries" to insulate their economies from changes in "international balances, which immediately reflect foreign disturbances and developments," and, more important, to influence day to day, week to week, and seasonal fluctuations of exchange rates, "especially those arising from the operations of speculators," to facilitate "the transition from one level of exchange rates to another," and "within certain limits to set the level of exchange rates. . The determination and maintenance of the external value of its currency is the main task of a Stabilization Fund" (see the Harry Dexter White Papers in the Seeley G. Mudd Manuscript Library, Princeton University, box 2, item 6.e).

2. The suggestion that Congress might be requested to appropriate additional funds to be used by the ESF, to my knowledge, was made on only one occasion. On January 14, 1948, in testimony before the Senate Foreign Relations Committee on financing the European Recovery Program, Treasury Secretary John W. Snyder proposed extending stabilization loans to European countries, adding, "At the appropriate time, Congress may then be requested to appropriate additional funds to be used by the United States Stabilization Fund to make those loans" (Treasury A.R. 1948, p. 300).

3. Unlike the Federal Reserve, the ESF is not required to transfer any of its earnings to the Treasury General Fund. 
4. One example of a use of the ESF other than for foreign exchange market intervention or stabilization loans is that, before fiscal 1980, "the administrative expenses for international programs, formerly funded by the Exchange Stabilization Fund, became a separate international affairs appropriation" (Treasury AR 1980, p. 105).

Until 1980 ESF annual and quarterly reports show gross income, expenses to operate the ESF, and net income. Thereafter, only ESF net income has been shown in its reports, as its expenses were shifted to the general government budget.

5. In Britain lagged publication of EEA figures began in 1937. In June 1937, the Chancellor disclosed total holdings of gold in the EEA and Issue Department on March 31, and subsequently made similar announcements every six months (Sayers 1976, II, P. 490). Foreign exchange balances on March 31 , 1937, were stated as "not more than a trifling amount." They were actually about $\mathbf{f} 7 \mathrm{~m}$.

6. Gold was held as an ESF asset only until 1975. See the discussion in section 2C. below. Note, however, that at IMF gold auctions in 1977, the Treasury purchased gold which it sold to the ESF (Treasury AR 1977, p. 158). The official source does not explain why the ESF acquired this gold and how it disposed of it. An entry for gold appears on the ESF balance sheet at the end of the first three quarters of 1977 and not thereafter.

7. In 1941 Morgenthau instructed the Treasury staff to begin work on postwar international monetary problems (Treasury AR 1945, Exhibit 51, p. 415). Harry Dexter White was the author of the U.S. Treasury draft of the Bretton Woods Agreement.

8. A second change made by the Bretton Woods Agreement Act was the creation by Section 4(a) of a National Advisory Council "to coordinate the policies and 
operations of the representatives of the United States on the Fund and the Bank and of all agencies of the Government which make or participate in making foreign loans or which engage in foreign financial, exchange or monetary transactions." The Secretary of the Treasury was chairman of the Council, and the Secretaries of State and Commerce, the Chairman of the Board of Governors and of the Board of Trustees of the Export-Import Bank were members. The agencies covered by the act were to inform the Council of their activities. (As an aside, one may question the appropriateness of including the Chairman of the Federal Reserve System in this roster of Executive Branch representatives.)

According to the Council. "The International Monetary Fund was projected to help achieve stability of exchange rates" (Treasury AR 1946, 302), hence might have been expected to preempt the ESF role. In fact, the ESF role before 1962 was hardly diminished. Despite its exchange-rate implications, the AngloAmerican Loan Agreement dated December 6, 1945 (approved July 15, 1946, by joint resolution of Congress), that authorized the Secretary of the Treasury to make $\$ 3,750$ million available as a line of credit to the United Kingdom, did not involve the ESF, presumably because the size of the loan was clearly in excess of the capacity of the ESF (Treasury AR 1947, 51).

In May 1976, however, the ESF had the capacity to lend the Bank of England $\$ 1$ billion. The Federal Reserve lent a like amount (Treasury AR 1976, p. 86). Since the Federal Reserve had a $\$ 3$ billion swap line with the Bank of England, it could itself have provided the $\$ 2$ billion. However, then Chairman Arthur F. Burns insisted on ESF participation as the price for his agreement with a Treasury plan to enforce British financial discipline (Burk.and Cairncross 1992, p. 42).

9. ESF balances of foreign currencies are to be distinguished from foreign 
currency balances held in Treasury and in agency accounts that were acquired without purchase with dollars.

10. Two official statements support this interpretation. In Section VI on "Methods of Acquiring and Selling Foreign Currencies" (see the document, "Authorization Regarding Open Market Transactions in Foreign Currencies"), the FOMC included transactions with the ESF. In Section 4, "Transactions in Forward Exchange" (see the document, "Guidelines for System Foreign Currency Operations"), referred to the Federal Reserve Bank of New York, where authorized, taking over from the ESF "outstanding contracts for forward sales or purchases of authorized currencies" (Board AR, 1962, Pp. 59, 63).

11. These were lines of credit the Federal Reserve established with the central banks of the leading European countries providing for the right of the U.S. to draw on a foreign currency up to a specified ceiling for a specified term, and the reciprocal right of the foreign central bank to draw on U.S. dollars at the current exchange rate for a matching sum and term.

12. Chairman Greenspan was eloquent in 1991 in opposing the Treasury's proposal that would authorize the Federal Reserve Banks to lend up to $\$ 25$ billion to the FDIC to absorb losses sustained by the Bank Insurance Fund in resolving failed banks. He stated: "Not only would use of the Reserve Banks for funding the BIF serve no economic purpose, it could create potential problems of precedent and perception of the Federal Reserve. In particular. the proposal involves the Federal Reserve directly funding the government. The Congress has always severely limited and, more recently, has forbidden the direct placement of Treasury debt with the Federal Reserve, apparently out of concern that such a practice could compromise the independent conduct of monetary policy and would allow the Treasury to escape the discipline of selling its debt directly to the market. . . . In addition, if implementation 
of the proposal created a precedent for further loans to the BIF or to other entities, the liquidity of the Federal Reserve's portfolio could be reduced sufficiently to create concerns about the ability of the Federal Reserve to control the supply of reserves and, thereby, to achieve its monetary policy objectives" (FRB June 1991, pp. 435-36).

Chairman Greenspan has not been equally opposed to Federal Reserve loans to the ESF. In what respect does warehousing differ from lending to the BIF? 13. To balance the suggestion made here of a greater ESF influence than is commonly assigned to it, let me note an erroneous attribution of greater ESF influence than it actually had. A recent paper asserts that the ESF played a domestic monetary role in the control of excess reserves in 1936-37 (Calomiris and Wheelock 1996). Inactive gold was held in the Treasury's General Fund, not the ESF. 


\section{LITERATURE CITED}

Board of Governors of the Federal Reserve System. Annual Report. 1934-94.

Broaddus, Jr., J. Alfred and Marvin Goodfriend. "Foreign Exchange Operations and the Federal Reserve." Annual Report of the Federal Regerve Bank of Richmond, 1996.

Burk, Kathleen, and Alec Cairncross. 'Goodbye, Great Britain': The 1976 IMF Crisis.New Haven: Yale University Press, 1992.

Calomiris, Charles W. and David C. Wheelock. "Was the Great Depression a Watershed for American Monetary Policy?" NBER Pre-Conference version, 1996.

Clarke, Stephen V. O. Central Bank Cooperation, 1924-31. New York: Federal Reserve Bank of New York, 1967.

Drummond, Ian M. The Floating Pound and the Sterling Area, 1931-1939. Cambridge: Cambridge University Press, 1981.

Federal Open Market Committee Meeting. Transcript. Processed. March $27,1990$. Federal Reserve Bulletin. 1980-96.

Gold, Joseph. "Mexico and the Development of the Practice of the International Monetary Fund." World Development 16 (No. 10, 1988), pp. 1127-42.

Hall, N.F. The Exchange Equalisation Account. London: Macmillan, 1935. International Monetary Fund, Treasurer's Department. Users' Guide to the SDR: A Manual of Transactions and Operations in SDRs. Washington, D.C.: International Monetary Fund, 1995.

Mulford, David. "Review of Treasury Department's Conduct of International and Foreign Policy." Hearings before the House of Representatives Committee on Banking, Finance, and Urban Affairg. Serial No. 101-63, 1019t Cong. 2d Sess. August 14, 1990. 
Parig, Jameg D. Monetary Policies of the United States, 1932-1938. New York: Columbia University Press, 1938.

Sayerg, Richard S. The Bank of England, 1891-1944. 3 vols. Cambridge: Cambridge University Press, 1976.

Todd, Walker F. "Disorderly Markets: The Law, History, and Economics of the Exchange Stabilization Fund and U.S. Foreign Exchange Market Intervention." Research in Financial Services Public and Private Policy. vol.4. Greenwich, CT: JAI Press, 1992, pp. 111-79.

Treasury Bulletin. 1940-1996.

Truman, Edwin M. "The Mexican Peso Crisis: Implicationg for International Finance." Federal Reserve Bulletin 82 (March 1996). pp. 199-209.

U.S. Secretary of the Treasury. Annual Report on the State of the Finances. 1934-1979.

Volcker, Paul, and Toyoo Gyohten. Changing Fortunes: The World's Money and the Threat to American Leadership. New York: Times Books, 1992. 
Table 1

Principal Noncash Assets of the ESF at Five-Year Intervals, 1935-95

\begin{tabular}{|c|c|c|c|c|c|}
\hline \multirow[b]{2}{*}{$\begin{array}{l}\text { End } \\
\text { of } \\
\text { June }\end{array}$} & & \multicolumn{4}{|c|}{ Principal Noncash Assets } \\
\hline & Total Assets ${ }^{\mathrm{a}}$ & $\begin{array}{c}\text { U.S. } \\
\text { Govemment } \\
\text { and Foreign } \\
\text { Securities }\end{array}$ & $\begin{array}{l}\text { Foreign } \\
\text { Exchange }\end{array}$ & Gold & \begin{tabular}{|c} 
Special \\
Drawing \\
Rights
\end{tabular} \\
\hline & \multicolumn{5}{|c|}{ (S Millions) } \\
\hline & (1) & (2) & (3) & (4) & (5) \\
\hline 1934 & 200.0 & 38.2 & 0 & $50.6^{\mathrm{d}}$ & \\
\hline 1935 & 205.8 & 26.8 & 0.02 & 0 & \\
\hline 1940 & 244.4 & 10.4 & 19.12 & 86.0 & \\
\hline 1945 & 290.4 & 20.4 & $24.09^{b}$ & 80.0 & \\
\hline 1950 & 301.5 & 20.0 & 27.60 & 99.9 & \\
\hline 1955 & 314.7 & 25.0 & 0 & 52.2 & \\
\hline 1960 & 330.2 & 60.0 & $25.00^{\mathrm{c}}$ & 40.4 & \\
\hline 1965 & 517.4 & 317.6 & 80.67 & 115.2 & \\
\hline 1970 & $2,560.8$ & 45.2 & 409.29 & 522.0 & 957. \\
\hline 1975 & $4,038.8$ & $1,451.4$ & 0.27 & c & 2,417 \\
\hline 1980 & $11,354.0$ & $4,036.1$ & $3,251.71$ & c & $3,781.7$ \\
\hline 1985 & $12,878.1$ & $3,332.3$ & $3,228.48$ & c & $6,196.1$ \\
\hline 1990 & $26,346.9$ & $1,021.0$ & $13,060.12$ & c & $10,490.5$ \\
\hline 1995 & $42,572.9$ & 410.9 & $28,997.18$ & c & 11,868 . \\
\hline
\end{tabular}

a) Excludes $\$ 1.8$ billion in gold account at Treasurer of U.S. 1934-45, used in 1947 to pay for part of U.S. subscription to IMF.

b) Includes $\$ 5$ million due from Government of Cuba.

c) Due from Argentine central bank.

d) Includes $\$ 30$ million in silver.

e) Includes Mexican pesos valued at $\$ 9$ billion, and foreign securities.

Source: Cols. 1-5, Treasury Bulletin; AR Treasury, 1940, p. 789, for 1934-35. 
Table 2

Capital Gains (Losses) and Interest Earnings on ESF Assets

at Five-Year Intervals, 1940-95

( $\$$ Millions)

\begin{tabular}{|c|c|c|c|c|c|c|}
\hline \multirow[b]{2}{*}{$\begin{array}{c}\text { Year Ending } \\
\text { June } 30\end{array}$} & \multicolumn{2}{|c|}{ Capital Gains (Losses) } & \multirow[b]{2}{*}{$\begin{array}{l}\text { Change in } \\
\text { SDR } \\
\text { Valuation }\end{array}$} & \multicolumn{3}{|c|}{ Interest Earnings on } \\
\hline & Gold & Foreign & & SDRs & $\begin{array}{l}\text { U.S. Government } \\
\text { and Foreign } \\
\text { Securities }\end{array}$ & $\begin{array}{l}\text { Foreign } \\
\text { Exchange }\end{array}$ \\
\hline 1940 & 3.8 & 0.40 & & & $\overline{0.2}$ & $\overline{0.3}$ \\
\hline 1945 & 26.9 & a & & & 0.5 & a \\
\hline 1950 & 2.6 & 0.10 & & & 0.5 & 0.5 \\
\hline 1955 & 1.1 & a & & & 0.6 & a \\
\hline 1960 & 2.3 & a & & & 3.0 & 0.5 \\
\hline 1965 & 0.2 & a & & & 19.8 & 4.4 \\
\hline 1970 & (22.8) & a & & 0.1 & 0.5 & 56.6 \\
\hline 1975 & & $(0.50)$ & 32.8 & $(65.7)$ & 162.1 & $(0.2)$ \\
\hline 1980 & & 271.20 & (39.8) & $(104.1)$ & 553.2 & 11.4 \\
\hline 1985 & & $(125.90)$ & $(9.7)$ & 75.5 & 244.3 & 165.4 \\
\hline 1990 & & 1020.20 & 202.9 & 308.8 & 73.9 & 826.0 \\
\hline 1995 & & 2963.60 & 295.5 & 153.8 & 313.8 & 799.6 \\
\hline
\end{tabular}

${ }^{a}$ Less than one hundred thousand 


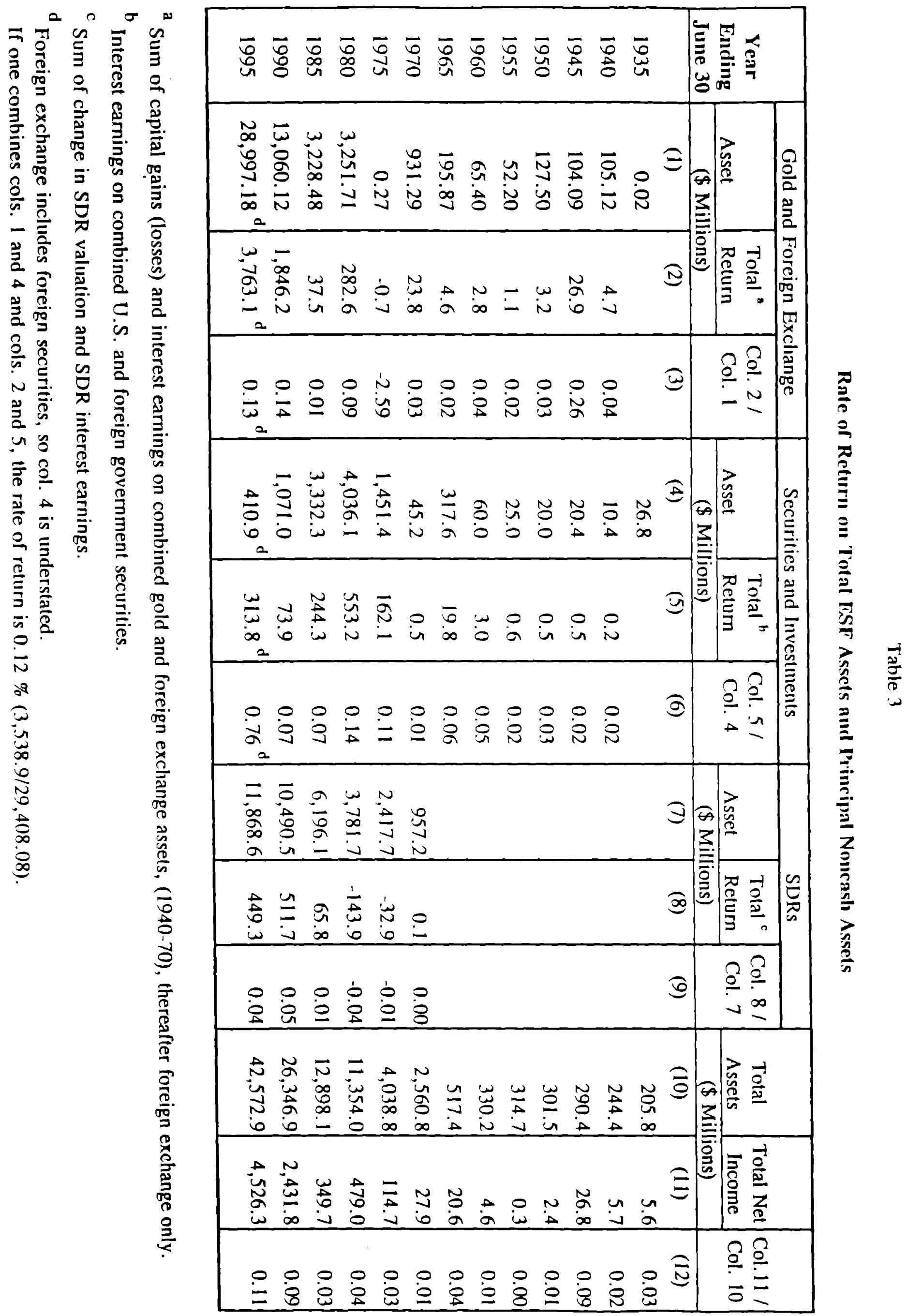

